УДК 346.7:356.32(477)(091)“18/19”

DOI https://doi.org/10.32837/yuv.v0i3.1958

\author{
В. Панасюк, \\ аспірант \\ Донецького національного університету імені Василя Стуса
}

\title{
ВИДИ НАДАННЯ В ОРЕНДУ ВІЙСЬКОВОГО МАЙНА
}

Для підвищення ефективності використання військового майна без шкоди бойовій та мобілізаційній готовності нині дозволено здійснення такої господарської діяльності у Збройних силах як надання в оренду певного майна. Організація i провадження такої діяльності залежить від багатьох чинників, серед яких можна виділити iï види.

На практиці надання в оренду військового майна має низку особливостей правового регулювання, які зумовлені видом майна, суб'єктним складом орендодавців та ін. Водночас такі особливості суттєво ускладнюють цей вид діяльності.

У законодавстві надання в оренду майна у цілому можна виокремити з урахуванням видів оренди залежно від форми власності (Закон України «Про оренду державного і комунального майна») [1]; від об'єкта оренди (закони України «Про оренду землі» [2], «Про аквакультуру» [3], «Про енергетичну ефективність будівель» [4], Водний кодекс України) [5]. Відносно військового майна види надання в оренду залежно від суб'єкта оренди представлено у Законі України «Про господарську діяльність у Збройних силах України» [6], Законі України «Про Збройні сили України» [7], Постанові Кабінету Міністрів України «Про затвердження Порядку надання дозволу військовим частинам на передачу закріпленого за ними рухомого та нерухомого майна в оренду» [8]. За іншими критеріями конкретизовано у підзаконних нормативно-правових актах. Разом із тим положення щодо видів надання в оренду військового майна потребують подальшого вдосконалення.

У теорії загальні питання оренди майна досліджували І.В. Борщевський [15], Н.В. Мороз [16], Е.В. Вакулович [17], А.Г. Брунь [18], В.В. Романів [19] та ін. Питання оренди саме військового майна опосередковано досліджували Е.Г. Бойченко [20] та В.В. Мусієнко [21]. Проте питання видів надання в оренду військового майна окремо не досліджувалися.

Наведене вказує на актуальність заявленої теми дослідження, метою якого є конкретизація видів надання в оренду військового майна.

Військове майно - це державне майно, закріплене за військовими частинами, закладами, установами та організаціями Збройних сил України (далі - військові частини). До військового майна належать будинки, споруди, передавальні пристрої, всі види озброєння, бойова та інша техніка, боєприпаси, пально-мастильні матеріали, продовольство, технічне, аеродромне, шкіперське, речове, культурно-просвітницьке, медичне, ветеринарне, побутове, хімічне, інженерне майно, майно зв'язку тощо (стаття 1 Закону України «Про правовий режим майна у Збройних силах України» від 21 вересня 1999 р.), певну частину якого дозволено надавати в оренду [8].

Для мети цього дослідження за основу взято визначення оренди як заснованого на договорі строкового 
платного користування майном, необхідним орендареві для здійснення підприємницької та іншої діяльності (ст. 2 Закону України «Про оренду державного i комунального майна» від 10 квітня 1992 р. (утратив чинність)), яке більш коректне, ніж чинний закон відображає сутність таких відносин.

При цьому надання в оренду військового майна - це вид економічної діяльності 3 передання у строкове платне користування певного такого майна, яке здійснюється для провадження підприємницької та іншої діяльності у межах і в порядку, встановлених законом.

Види надання в оренду військового майна не визначено на законодавчому рівні, та їх можна виокремити 3 аналізу нормативно-правових актів, що регулюють відповідні відносини.

Основним критерієм поділу цього виду економічної діяльності є об'єкти оренди, якими є нерухоме та рухоме майно, на що зверталася увага в науковій літературі (B.B. Мусієнко, I. В. Борщевський, Е.В. Вакулович, Н.В. Мороз, В.В. Романів). На такий критерій указує Класифікація видів економічної діяльності ДК 009:2010 (далі - КВЕД), в якій надання в оренду нерухомого майна i надання в оренду рухомого майна розташовані в різних секціях [14].

На доцільність виокремлення видів цієї діяльності щодо військового майна саме за цим критерієм указують Постанова Кабінету Міністрів України від 11 травня 2000 р. № 778 «Про затвердження Порядку надання дозволу військовим частинам Збройних сил на передачу закріпленого за ними рухомого та нерухомого майна в оренду» та відповідні інструкціï [9]. Так, надання в оренду рухомого майна передбачено Інструкцією про організацію передачі в оренду та укладення договорів оренди рухомого військового майна, затвердженою Наказом Міністерства оборони України № 155 від 21 березня
2017 р. [11]; під час конкурсного відбору щодо оренди нерухомого військового майна - Положенням про конкурсний відбір суб'єктів оціночної діяльності у разі оренди нерухомого військового майна, затвердженим Наказом Міністерства оборони України № 156 від 6 квітня 2015 р. [12].

Зазначені нормативно-правові акти певною мірою розрізняють відносини оренди рухомого і нерухомого військового майна, проте надання в оренду такого майна як виду господарської діяльності регулюють лише частково.

Своєю чергою, кожен із названих двох видів діяльності за цим критерієм можна поділити на окремі підвиди, оскільки як рухоме, так і нерухоме майно не $€$ однорідним, що вимагає врахування під час визначення правового режиму такої діяльності 3 кожним видом майна. Так, взявши за основу підхід І.В. Борщевського щодо поділу нерухомого майна [15], можна виокремити такі види надання в оренду нерухомого військового майна, як надання в оренду земельних ділянок, надання в оренду будівель, інших капітальних споруд та надання в оренду речей, на які режим нерухомої речі може бути поширений, повітряні та морські судна, судна внутрішнього плавання, космічні об'єкти.

На практиці такий поділ надання в оренду нерухомого військового майна слідує, зокрема, 3 інформаціï про нерухоме майно, яке включене до діючих переліків та пропонується до передачі в оренду станом на 01.12.2018, яка розміщена на офіційному сайті Міністерства оборони України. У графі найменування військового майна зазначено нежитлові приміщення, будівлі, технічні майданчики, окремі частини нежитлових приміщень, котельні (частини труби в котельні тощо), споруди (пожежні водоймища), технічні споруди, вишки освітлювальні тощо.

У такому виді діяльності, як надання в оренду рухомого майна, 
найбільш поширеними $€$ виокремлення надання в оренду транспортних засобів та інших рухомих речей, що має значення і для надання в оренду військового майна. Так, взявши за основу позицію Е.В. Вакулович щодо оренди транспортних засобів, можна назвати такий вид діяльності щодо оренди рухомого військового майна як надання в оренду транспортного засобу, комплексу послуг для забезпечення нормального використання транспортного засобу, тобто послуг із керування і технічної експлуатації (з екіпажем) і без надання таких послуг (без екіпажа). Другим видом діяльності за цим критерієм буде надання в оренду іншого рухомого військового майна.

Своєю чергою, надання в оренду транспортних засобів та устаткування найбільш повно можна представити з урахуванням кодів КВЕД: 71.10 .0 - оренда автомобілів, 71.21.21.0 - оренда інших наземних транспортних засобів та устаткування, 71.22.0 - оренда водних транспортних засобів та устаткування, 71.23 .0 - оренда повітряних транспортних засобів та устаткування, 71.32 .0 - оренда будівельних машин та устаткування, 71.33.0 - оренда офісних машин та устаткування, включаючи обчислювальну техніку, 71.34.0 оренда інших машин та устаткування, що закріплено у Переліку видів господарської діяльності, здійснення якої дозволяється військовим частинам Збройних сил, затвердженому Постановою Кабінету Міністрів України від 25 липня 2000 р. № 1171 [10].

Практика таких відносин $€$ недостатньо доступною, крім судової практики, яка певною мірою вказує на наведений поділ. Так, наприклад, 03.04.2012 між військовою частиною 2269 Національної гвардії України (орендодавець, позивач-2) та приватним акціонерним товариством «Авіакомпанія «Українські вертольоти» (орендар, відповідач) укладено договір № 5/12-ФС оренди повітряного судна Мi-8MT N 94917, відповідно до пункту 1.1 якого орендодавець передає, а орендар приймає у строкове платне користування державне окреме індивідуально визначене майно - вертоліт Mi-8MT, заводській номер 94917, залишкова вартість - 2794 428,00 грн (без ПДВ), який перебуває на балансі орендодавця [22].

Отже, поділ надання оренди військового майна за таким критерієм, як об'єкти оренди, має дворівневий характер і є цілком виправданим для уточнення правового режиму цієї економічної діяльності.

Ще одним критерієм, який має значення для правового режиму економічної діяльності з надання в оренду військового майна, є суб’єктний склад такої діяльності. Відповідно до ч. 3 ст. 3 Закону України «Про Збройні сили України», організаційно Збройні сили України складаються з органів військового управління, з'єднань, військових частин, військових навчальних закладів, установ та організацій [7]. Водночас суб'єктний склад саме господарської діяльності, у тому числі й надання в оренду, визначено Законом України «Про господарську діяльність у Збройних силах України», яким до таких суб'єктів віднесено військові частини, заклади, установи та організації Збройних сил України, які утримуються за рахунок коштів державного бюджету України, ведуть відокремлене господарство, мають кошторис надходжень та видатків, рахунки в установах банків, печатку із зображенням Державного герба України і своїм найменуванням (ст. 3).

На практиці такими суб'єктами цієї господарської діяльності виступають також різні юридичні особи. Так, це можуть бути квартирно-експлуатаційні відділи, зокрема такий відділ м. Одеси, який є установою, був одним із позивачів під час розгляду справи № 916/559/17 про розірвання договору оренди [24]. Найчастіше таким суб'єктом є військова

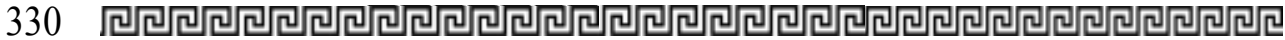


частина, наприклад військова частина А2171 виступала позивачем під час вирішення справи № 916/146/15-г (Постанова Верховного Суду від 8 серпня 2018 р.) про розірвання договору оренди військового майна [25]. Водночас це можуть бути і підприємства, наприклад одним із позивачів під час вирішення справи № 908/1064/17 (Постанова Верховного Суду від 22 травня 2018 р.) про визнання договору оренди землі недійсним виступало державне підприємство Міністерства оборони України «Запорізький автомобільний ремонтний завод» [26].

Отже, суб'єктами надання військового майна в оренду можуть бути чотири види суб'єктів Збройних сил України, хоча у подальшому тексті вказаного Закону йдеться лише про військові частини без застереження, що таке поняття $€$ узагальнюючим для всіх вищезазначених суб'єктів. Певною мірою уточнюються такі положення Закону Постановою Кабінету Міністрів України від 11.05.2000 № 778, яким затверджено Порядок надання дозволу військовим частинам Збройних сил на передачу закріпленого за ними рухомого та нерухомого майна в оренду [9], яким, незважаючи на назву, передбачено, що порядок визначає процедуру надання дозволу військовим частинам, закладам, установам та організаціям Збройних сил. Наведені положення законодавства стали підставою для висновків щодо визнання всіх перерахованих суб'єктів військовими частинами (Е.Г. Бойченко), проте спростувати таку думку можна на основі аналізу нормативно-правових актів, що регулюють окремі відносини у Збройних силах України, в яких передбачено різні умови, правила, вимоги щодо вї̈ськових частин та інших суб'єктів господарської діяльності у Збройних силах.

Проведений аналіз дає можливість запропонувати поділ надання в оренду військового майна за умови, що таке майно не повинно підпадати під визначення озброєння та спеціальної техніки, стосовно яких існує заборона для передачі в оренду, на такі види:

а) залежно від об'єкта оренди:

надання в оренду нерухомого військового майна (земельних ділянок, оренда будівель та інших капітальних споруд та оренда речей, на які режим нерухомої речі може бути поширений, повітряні та морські судна, судна внутрішнього плавання, космічні об'єкти);

надання в оренду рухомого військового майна (автомобілів, інших наземних транспортних засобів та устаткування, водних транспортних засобів та устаткування, повітряних транспортних засобів та устаткування, будівельних машин та устаткування, офісних машин та устаткування, включаючи обчислювальну техніку, інших машин та устаткування тощо);

б) залежно від суб’єктного складу діяльності: надання в оренду військовими частинами, закладами, установами та організаціями Збройних сил України.

Подальше дослідження теми необхідно присвятити аналізу та доопрацюванню правового режиму запропонованих видів надання оренди військового майна, уточненню суб'єктного складу такої діяльності.

У статті досліджуються види надання в оренду військового майна. За основу дослідження взято визначення військового майна відповідно до законів України «Про Збройні сили України», "Про господарську діяльність у Збройних силах України»; визначення оренди майна відповідно до чинного $i$ nопереднього законодавства про орендні відносини. 3 урахуванням Класифікації видів економічної діяльності ДК 009:2010 та особливостей господарської діяльності у Збройних силах України уточнено, що надання в оренду військового майна - 
це вид економічної діяльності з передання у строкове платне користування певного такого майна, яке здійснюеться для провадження підприємницької та іншої діяльності у межах $i$ в порядку, встановлених законом.

Проведено загальний аналіз наукових досліджень щодо надання в оренду майна у иілому $i$ військового зокрема. Представлено аналіз судової практики щодо оренди військового майна (постанови Верховного Суду від 11.09.2018 у справі № $911 / 747 / 17$, віة 28.02.2018 y cnpaві № 924/247/17, віة 03.07.2018 y справі № 916/559/17, від 08.08.2018 y справі № 916/146/15-2, ві 22.05.2018 у справі № 908/1064/17), виявлено проблемні питання.

Виокремлено кілька критеріїв поділу надання в оренду військового майна, основним серед яких $з$ урахуванням особливостей військового майна є об'єкти оренди (рухоме і нерухоме військове майно).

Обгрунтовано доцільність виокремлення ще одного критерію, який має значення для правового режиму економічної діяльності з надання в оренду військового майна, яким є суб'єктний склад такої діяльності. Досліджено підходи до суб’єктного складу таких відносин $у$ науковій літературі та законодавстві, запропоновано види надання в оренду військового майна за цзим критерієм.

Результатами дослідження $\epsilon$ пропозиції щодо поділу надання в оренду військового майна як виду господарської (економічної) діяльності на такі види: а) залежно від об'єкта оренди: надання в оренду нерухомого військового майна (земельних ділянок, оренда будівель ma інших капітальних споруд ma оренда речей, на які режим нерухомої речі може бути поширений, повітряні та морські судна, судна внутрішнього плавання, космічні об’єкти); надання в оренду рухо- мого військового майна (автомобілів, інших наземних транспортних засобів та устаткування, водних mранспортних засобів та устаткування, повітряних транспортних засобів та устаткування, будівельних машин та устаткування, офісних машин та устаткування, включаючи обчислювальну техніку, інших машин та устаткування тощо); б) залежно від суб'єктного складу діяльності: надання в оренду військовими частинами, закладами, установами та організаціями Збройних сил України.

Наголошується, що подальші наукові розвідки необхідно присвятити дослідженню та доопраиююванню правового режиму запропонованих видів надання оренди військового майна, уточненню суб'єктного складу такоӥ діяльHOCMi.

Ключові слова: оренда, військове майно, види.

Panasiuk V. Types of military property lease

The article examines the types of leasing of military property. The research is based on the definition of military property according to the laws of Ukraine "On the Armed Forces of Ukraine», "On Economic Activity in the Armed Forces of Ukraine»; on the definition of the property lease in accordance with current and previous legislation on lease relations. Taking into account the Classification of Economic Activities SC 009: 2010 and the peculiarities of economic activity in the Armed Forces of Ukraine, it was specified that the military property lease is a type of economic activity for the transferring of certain property, which is carried out for business and other activities within and in the way defined by law.

An overall analysis of scientific research on the lease of property in general and military, in particular, was carried out. The analysis of 
the court practice on the lease of military property (Supreme Court rulings dated 11.09.2018 in case № 911 / $747 / 17$, dated 28.02.2018 in case № 924 / 247/17, dated 03.07.2018 in case №916 / 559/17, dated 08.08.2018 in case № 916 / $146 / 15-g$, dated 22.05.2018 in case № 908 / 1064/17) was submitted and its problematic issues were also identified.

Several criteria for the division of the military property lease, the main of which, taking into account the characteristics of military property, are the objects of lease (movable and immovable military property) were determined.

The expediency of distinguishing another criterion that is important for the legal framework of economic activity for the lease of military property, which is the subject of such activities, was specified. The approaches to the subjective composition of such relations in the scientific literature and legislation were studied, the types of leasing of military property according to this criterion were offered.

The results of the research are the suggestions for the division of the lease of military property as a type of economic (economic) activity into the following types: a) depending on the lease object - the lease of military real estate (land, rent of buildings and other capital structures and rent of things to which the framework of immovable property may be extended, aircraft and ships, inland vessels, space objects); lease of movable military property (cars, other land vehicles and equipment, water vehicles and equipment, air vehicles and equipment, construction machinery and equipment, office machinery and equipment, including computers, other machinery and equipment, etc.); b) depending on the subjective composition of the activity -leasing by military units, institutions, establishments and organizations of the Armed Forces of Ukraine.

It was emphasized that further research should be devoted to the study and refinement of the legal framework of the proposed types of military property lease, clarification of the subject composition of such activities.

Key words: lease, military property, types.

\section{Література}

1. Про оренду державного $і$ комунального майна : Закон України № 2269-ХII від 10.04.1992 (у ред. Закону № 2269-ХII від 10.04.1992). Відомості Верховної Ради України. 1992. № 30. Cm. 416.

2. Про оренду землі: Закон України №161-XIV від 06.10.1998 (у ред. Закону № 124-IX від 16.10.2020). Відомості Верховної Ради України. 1998. № 46. Ст. 280.

3. Про аквакультуру : Закон Украінни № 5293-VI від 18.09.2012 (у ред. Закону № 2059-VIII від 18.12.2017). Відомості Верховної Ради України. 2013. № 43. Cm. 616 .

4. Про енергетичну ефективність будівель : Закон України № 2118-VIII від 22.06.2017 (у ред. Закону № 199-IX від 01.12.2020). Відомості Верховної Ради України. 2017. № 33. Ст. 359.

5. Водний кодекс України від 06.06.1995 (у ред. № 124-IX від 16.10.2020). Відомості Верховної Ради України. 1995. № 24. Cm. 189 .

6. Про господарську діяльність у Збройних силах України: Закон України № 1076-XIV від 21.09.1999 (у ред. Закону № 310-VIII від 26.04.2015). Відомості Верховної Ради України. 1999. № 48. Ст. 408.

7. Про Збройні сили України : Закон України № 1934-XII від 06.12.1991 (у ред. Закону № 2581-VIII від 04.11.2018). Відомості Верховної Ради України. 2000. № 48. Cm. 410 .

8. Про правовий режим майна у Збройних силах України : Закон Украӥни № 1075-XIV від 21.09.1999 (у ред. Закону № 255-VII від 12.06.2013). Відомості Верховної Ради України. 1999. № 48. Ст. 407.

9. Про затвердження Порядку надання дозволу військовим частинам Збройних сил на передачу закріпленого за ними рухомого та нерухомого майна в оренду: Постанова Кабінету Міністрів України 


\section{ЮРИАИЧНИЙ ВІСНИК, 2020/3}

№ 778 від 11.05.2000 (у редакиії Закону № 581-2009-n віة 19.06.2009). Офіційний вісник України. 2000. № 20. Ст. 821.

10. Про затвердження переліку видів господарської діяльності, здійснення якої дозволяеться військовим частинам Збройних Сил. Постанова Кабінету Міністрів України № 1171 від 25.07.2000 (y ред. Закону № 880-2016-n віО 07.12.2016). Офімійний вісник України. 2000. № 30. Cm. 1279. С. 117.

11. Про затвердження Інструкиії про організацію передачі в оренду та укладення договорів оренди рухомого військового майна: Наказ Міністерства оборони України № 155 від 21.03.2017. Офіційний вісник України. 2017. № 35. Cт. 1107. С. 12 .

12. Про затвердження Положення про конкурсний відбір суб'єктів оиіночно діяльності у випадках оренди нерухомого військового майна: Наказ Міністерства оборони України від 06.04.2015 № 156 (ред. від 17.11.2017 № z1274-17). Офіuійний вісник України. 2015. № 49. Ст. 1587. С. 94.

13. Національний класифікатор України. Класифікація видів економічної діяльності ДК 009:2010 : Наказ Держспоживстандарту України від 11 жовтня 2010 p. № 457. Київ, 2010. 44 c.

14. Борщевський I.В. Договір найму (оренди) нерухомого майна: дис. ... канд. юрид. наук : 12.00.03. Київ, 2004. 204 c.

15. Мороз М.В. Правові питання оренди майна державних підприємств : автореф. дис. ... канд. юрид. наук : 12.00.03. Харків, 2000. 20 c.

16. Вакулович Е.В. Договір оренди транспортних засобів : дис. ... канд. юрид. наук: 12.00.03. Харків, 2002. 163 с.

17. Брунь А.Г. Договір оренди земельних ділянок сільськогосподарського при- значення : дис. ... канд. юрид. наук : 12.00.03. Харків, 2003.

18. Романів В.В. Договір оренди нерухомого майна за иивільним законодавством України : дис. ... канд. юрид. наук : 12.00.03. Львів, 2015.

19. Бойченко Е.Г. Правове регулювання господарської діяльності військових частин Збройних сил України : дис. ... канд. юрид. наук : 12.00.04. Одеса, 2015. $241 \mathrm{c}$

20. Мусієнко В.В. Цивільно-правові аспекти договору оренди державного та комунального майна: дис. ... канд. юрид. наук : 12.00.03. Київ, 2003. 197 c.

21. Постанова Верховного Суду від 11.09.2018 у справі № 911/747/17. Є2uний державний реєстр судових рішень. URL: http: / / reyestr.court.gov.ua/Review/ 76385319 .

22. Постанова Верховного Суду віо 28.02.2018 у справі № 924/247/17. ЄӘuний державний реєстр судових рішень. URL: http: / / reyestr.court.gov.ua/Review/ 72486341 .

23. Постанова Верховного Суду від 03.07.2018 у справі № 916/559/17. ЄӘuний державний реєстр судових рішень. URL: http: / / reyestr.court.gov.ua / Review / 75241905.

24. Постанова Верховного Суду від 08.08.2018 у справі № 916/146/15-г. Єəuний державний реєстр судових рішень. URL: http: / / reyestr.court.gov.ua/ Review/ 75770366 .

25. Постанова Верховного Суду від 22.05.2018 у справі № 908/1064/17. Єduний державний реєстр судових рішень. URL: http: / / reyestr.court.gov.ua / Review / 74329974. 